\title{
From Paris to Dublin: Domestic Politics and the Treaty of Lisbon
}

\author{
Maurizio Carbone
}

\begin{abstract}
This article discusses the domestic politics of treaty reform in the European Union, from the failed referendum on the Constitutional Treaty held in France in May 2005 to the failed referendum on the Treaty of Lisbon held in Ireland in June 2008. A meticulous examination of the national level, it is argued here, helps us to better understand the European level and why some Member States manage to influence outcomes more than it would be expected. In particular, this article looks at the role played by actors beyond national governments, the impact of the political system and the general context on preference formation and inter-state bargaining, and the use that national negotiators made of ratification hurdles to receive extra concessions. More generally, by looking at the preparatory, negotiation and ratification process of the Treaty of Lisbon, this article aims to make a contribution to an emerging literature, which argues that we can no longer explain the evolution of the European Union without understanding the increased politicisation of the European project.
\end{abstract}

ON 13 DECEMBER 2007, THE HEADS OF STATE AND GOVERNMENT OF THE 27 MEMBER States of the European Union (EU) met in the capital of Portugal to sign the Treaty of Lisbon. This was the latest episode in the process of 'constitutional politics' that started in December 2001 with the Laeken Declaration. The ensuing Convention on the Future of Europe, which operated between February 2002 and July 2003, represents a unique experience in the history of the EU. In contrast to previous treaty reforms, when negotiations occurred in the context of a secretive inter-governmental conference (IGC), the establishment of the Convention was meant to set up a new method, allegedly more democratic and transparent. ${ }^{1}$ The draft Constitutional Treaty produced by the Convention was broadly accepted by the Member States in the 2003-04 IGC and signed in Rome in October 2004 under the Irish Presidency. The method of ratification varied across Member States, but an unprecedented number chose to consult their populations.

\footnotetext{
${ }^{1}$ The traditional method to revise a treaty starts with convening an IGC. Most of the negotiations take place in the preparatory group, which comprises representatives of foreign ministers. The highest level is represented by the heads of state and government, who meet to broker compromises and agree on a final text. Any treaty must be ratified by all Member States according to their constitutional requirements, through parliamentary approval or popular referendum (Beach 2005: 8-9).
}

This paper is based on the research that I conducted in view of the international symposium on "The Lisbon Treaty and the Future of the European Union", held at the University of Glasgow on $6^{\text {th }}-7^{\text {th }}$ December 2007. I want to thank participants in the workshop, the editor of JCER, and two anonymous reviewers for their helpful comments. I also want to gratefully acknowledge the support of the Political Studies Association (PSA) - including its Italian, French and German specialist groups - and the Scottish Jean Monnet Centre of European Excellence.

ISSN 1815-347X online. Carbone, M. (2009). 'From Paris to Dublin: Domestic Politics and the Treaty of Lisbon', Journal of Contemporary European Research, Vol. 5, No. 1, pp. 43-60. Available: http://www.jcer.net/ojs.index.php/jcer/article/view/173/126 
The negative outcome of the referendums in France and the Netherlands in May-June 2005 was expected to precipitate the European Union into one of the most serious crises of its 50-year history. Its predicted lethal effects, however, failed to materialise. Not only did the EU continue to function as before, but after a 'period of reflection', the German Presidency was able to restart the debate. Following the June 2007 European Council, a new IGC was convened to draft a Reform Treaty, which was eventually agreed under the Portuguese Presidency in October 2007. The new treaty, which took the name of the city where it was signed, maintained a large majority of the provisions agreed by the Convention and the following IGC, but it removed all the constitutional and statist references. Nevertheless, various Member States which, in some cases constrained by domestic structures and in other cases taking advantage of the new situation, managed to receive a number of concessions. The failure of the referendum in Ireland - the only country which had chosen that method of ratification represented a further stop to the EU's reform process.

This article explores the preparation, negotiations and ratification of the Lisbon Treaty, from the referendum on the ratification of the Constitutional Treaty held in France in May 2005 to the referendum on the Lisbon Treaty held in Ireland in June 2008. The aim of the article is to analyse the impact of domestic politics on one of the 'grand bargains' of European integration. By concentrating on Member States, I certainly do not want to claim that these are the sole forces behind change, ${ }_{1}^{2}$ nor do I want to argue that integration proceeds only in the context of IGCs. ${ }^{3}$ A meticulous examination of the national level, it is argued here, helps us to better understand treaty reform at the European level, or why some Member States manage to influence outcomes more than it would be expected. Drawing on a number of recent contributions in European integration theory, this article goes beyond liberal intergovernmentalism to integrate a number of actors and factors which are believed to play a significant role in shaping treaty reform outcomes: this includes actors beyond national governments, political systems, ratification hurdles and general context. ${ }^{4}$ More generally, this article aims to make a contribution to an emerging literature, which argues that we can no longer explain the evolution of the European Union without understanding the increased politicisation of the European project (Taggart 2005; Hix 2005; Checkel 2007; Hooghe and Marks 2009).

To do this, the article is divided into three broad sections. The first section presents the theoretical background on the role of domestic politics in the 'big bangs' of European integration. It starts from liberal intergovernmentalism, and then reviews the main criticisms made by institutionalists and constructivists and by scholars taking a comparative politics approach. The second section concentrates on the process that led to the adoption of the Treaty of Lisbon and its difficult ratification. The third section links the theoretical background and the empirical analysis, concentrating on the four issues mentioned above: actors, political system, ratification hurdles, and context. Moreover, considering that the domestic debate was significant mainly in those

\footnotetext{
${ }^{2}$ Scholars belonging to the supranationalist and constructivist traditions have emphasised the role of European institutions, norms, and past decisions (Christiansen 2002; Sverdrup 2002; Hix 2002; Beach 2005). In this sense, scholars in the neo-functionalist tradition have highlighted that integration is driven by transactions and exchanges between various types of supranational and sub-national actors, before and after IGCs (Stone Sweet and Sandholtz 1998; Marks, Hooghe and Blank 1996) though IGC bargaining leaves little room for their influence, thus making these approaches less applicable to treaty reform (Slapin 2008).

${ }^{3}$ Scholars in the neo-functionalist tradition have highlighted that integration is driven by transactions and exchanges between various types of supranational and sub-national actors, before and after IGCs (Stone Sweet and Sandholtz 1998; Marks, Hooghe and Blank 1996) - though IGC bargaining leaves little room for their influence, thus making these approaches less applicable to treaty reform (Slapin, 2008).

${ }^{4}$ Moravcsik (1993: 494) admits that liberal intergovernmentalism offers an inadequate treatment of the impact of domestic (f)actors - and not only businesses and economic interests - on the EU, particularly in cases of institutional and political bargains (Moravcsik and Nicolaïdis 1999; Magnette and Nicolaïdis 2004).
} 
countries that had not ratified the Constitutional Treaty, most of the examples used in this paper come from a restricted number of Member States.

\section{Understanding the Domestic Politics of Treaty Reform}

The European Union has been characterized by a series of treaty revisions, though its evolution cannot be reduced to the history of these intergovernmental bargains. Following the amendments agreed in the 1986 (Single European Act), 1991 (Maastricht), 1997 (Amsterdam), and 2000 (Nice) IGCs, the planned enlargement for the mid-2000s increased the need for further institutional reforms. The difficult negotiations before the Treaty of Nice, when national negotiators spent many days in hard bargaining over parochial issues rather than searching for solutions for the 'new Europe' thus leaving unresolved a number of institutional issues, showed that the traditional method for treaty reform had reached its limits (Christiansen 2008). The Convention on the Future of Europe was designed differently, in terms of composition and decision making rules. In fact, it comprised not only the representatives of the governments (including the candidate countries), but also delegates from the national parliaments, the European Parliament and the European Commission. Some argued that, as a consequence of the strong leadership of its President Giscard d'Estaing and the informal consensus rule, the Convention was able to agree on outcomes that had been rejected in earlier IGCs (Panke 2006; Magnette and Nicolaïdis 2004). Others maintained that the bargaining dynamics in reality did not differ much from previous negotiating rounds: the Convention simply reproduced the conflicts between Member States that had occurred in earlier IGCs (König and Hug 2006). ${ }^{5}$ The Constitutional Treaty, which broadly reflected the draft treaty produced by the Convention, was however rejected by the French and Dutch voters in 2005. The same fate befell its successor, the Treaty of Lisbon, which was rejected by the Irish voters in 2008. Clearly, the reform of the EU's institutional framework has been significantly affected by the increased politicisation of the EU issue in various Member States in so much that the national level of treaty reform can no longer be overlooked.

Linking national and European levels is not a novelty in the field of EU studies. In the early 1980s, Bulmer (1983) argued that there are two dimensions to this link: the domestic policy-making structures which are involved; the attitudes held within the Member States regarding the EU. ${ }^{6}$ Before that, in the late 1950 s Haas had argued that "national constituted groups" - mainly political elites - played a central role in European integration (cited in Checkel 2007). The most influential work for EU scholars working in this area is that of Robert Putnam and his famous two-level game metaphor (Putnam 1988). The idea is that the executive is engaged in simultaneous negotiations at the domestic and the international level. At the domestic level, it deals with societal concerns and pressures; while at the international level, it tries to make commitments that would not have detrimental effects back at home. More generally, liberal theories

\footnotetext{
${ }^{5}$ More generally, the work of the Convention has attracted a lot of attention from various research angles. A first group of scholars has analysed the process and actors (Dimitrakoupolos and Kassim 2004; Beach and Mazzuccelli 2007; König and Hug 2006; Laursen 2008); A second group has looked at its implications from a philosophical point of view (Dobson and Føllesdal 2004; Eriksen et al. 2004; Castiglione et al. 2005). A third group has looked at the negotiation process in light of the logics of arguing and bargaining (Panke 2006; Magnette and Nicolaïdis 2005; Risse and Kleine 2007).

6 The basic assumptions for this approach are five. First, the national polity - where governments, political parties, interest groups derive their legitimacy - is the basic unit in the EU. Second, each national polity has a different set of social and economic conditions which affects its national interest; ideology, structure of the state and the state's relationship to the external word play a central role. Third, it is not possible to separate a state's European policy from other domestic policies. Fourth, national governments play a central role in the negotiations, but they may be 'captured' by domestic interests and transnational forces, which restrict significantly their margin of manoeuvre. Fifthly, the behaviour of member states in the EU is shaped by various 'policy styles', which includes national political culture, strength of government and domestic actors, type of policy pursued (Bulmer 1983: 354-62).
} 
of international relations concentrate on the effects of state-society relations in shaping national preferences. Societal groups constrain, more or less, the priorities and policies of governments, depending on the policy area and the anticipated costs and benefits of the policy in question. It is not thus surprising that a vast literature has been increasingly assessing the role played by economic groups, bureaucracies, nongovernmental organisations, ideas in the 'foreign' policies of countries.

The most elaborated theory to explain outcomes in the IGCs is liberal intergovernmentalism, in which domestic politics takes a prominent role: "An understanding of domestic politics is a precondition for, not a supplement to, the analysis of the strategic interaction among states" (Moravcsik 1993: 481). In a refined version of his theory, Moravcsik (1998) divided the EU's decision-making process into three stages - (1) national preference formation; (2) inter-state bargaining; (3) institutional delegation - the first two of which are central to this article. Firstly, governments aggregate preferences at the national level, mostly on the basis of the economic interests of powerful domestic groups. True, the primary interest of governments is to remain in power and to do so they need the support of domestic voters, parties, interest groups, but they are ultimately sovereign in the definition of the national interest. Ideological and geopolitical considerations may play a role but this is secondary to commercial interests. Secondly, on the basis of fixed preferences, governments engage in hard bargaining as unitary actors and adopt various tactics (i.e. linking issues, side-payments, threats of exclusion) to affect outcomes. Decisions reflect the relative power of Member States and integration proceeds through lowest common denominator outcomes, mainly when there is a convergence of preferences of the three most powerful Member States - i.e. France, Germany, and the United Kingdom. Intergovernmental bargaining at the EU level may even strengthen the domestic autonomy of national governments vis-à-vis domestic groups, by weakening parliamentary control and loosen the control of powerful domestic interests. ${ }^{8}$ Liberal intergovernmentalism and its views of domestic politics have been criticised from various directions, and these criticisms are reviewed in the remainder of this section.

Drawing on comparative politics and policy literatures, Dimitrakopoulos and Kassim (2004), in a study devoted to the Convention, showed that the policy style and the political system of countries have a structuring effect on preference formation. ${ }^{9}$ The way a Member State deals with the EU's treaty reforms may be affected by its approach to problem-solving (anticipatory or reactive?) and the degree of participation of civil society in the policy process (consensual or based on coercion?). Similarly, various elements of the political system are likely to be relevant. This includes the composition of the government and the size of its majority, the power granted to the Prime Minister vis-à-vis other ministers, the influence of the Parliament, the ideology of political parties, the strength of interest groups and civil society, the role of bureaucratic politics, the overall process of coordination, the organization of territorial relations and territorial representation, the salience of EU membership in the public debate.

Along similar lines, Beach and Christiansen (2007), in a study on political agency in the EU's constitutional politics, argued that a wider range of actors beyond the head of the

\footnotetext{
${ }^{7}$ A discussion of this literature is beyond the scope of this paper. For sophisticated analyses and reviews on the link between domestic politics and international relations, see Moravcsik (1997), Milner (1997) and Gourevitch (2002). For a discussion of the impact of domestic politics on European integration and policy making in the EU, see Rosamond (2000) and Diez and Wiener (2004).

8 In the third stage, Member States delegate authority to supranational institutions to enhance the credibility of their commitments and solve problems of incomplete contracting, monitoring and compliance On the basis of this theory, Moravcsik (1998) explained outcomes in treaty negotiations from Messina to Maastricht, Moravcsik and Nicolaïdis (1999) the Treaty of Amsterdam, and Magnette and Nicolaïdis (2004) the Constitutional Treaty.

9 Dimitrakopoulos and Kassim (2004: 251) draw on the concept of policy style developed by Richardson (1982) when they define policy style as 'the standard operating procedures that societies develop for making and implementing policies'. On these issues, see also Closa (2004) and Jabko (2004).
} 
executive must be included to better understanding treaty reform. Opening the 'black box' of national interest, they maintain that "Treaty negotiations cut across the different levels of national interest representation, involving both politicians (at the ministerial and the prime ministerial level) and officials ... demonstrating their degree to which national interest representation in EU treaty reform is potentially fragmented both vertically and horizontally" (Beach and Christiansen 2007: 1165). ${ }^{10}$ Furthermore, the referendum is not always used to receive concessions at the EU negotiating table, but it may be called for domestic considerations, particularly in those countries where the EU issue is contentious and the referendum is considered the most appropriate instrument to involve citizens into the process (Closa 2007).

Taking an institutionalist perspective, two issues are of particular interest for this article, namely the veto power of Member States and the ratification procedure. ${ }^{11}$ While studies in the intergovernmental tradition place emphasis only on the largest Member States, institutionalists argue that all (types of) Member States must be taken into account, particularly when they are able to exercise veto power. This occurs principally when they perceive an issue as threatening their national sovereignty, the so-called vital issues; therefore by using their veto power, they can maintain the status quo. When vital issues are raised by one country, it is easier to deal with them by granting concessions. ${ }^{12}$ As for the ratification procedure, the general argument is that national negotiators try to get an advantage claiming that their hands are tied by their ratification processes, both parliamentary and popular. In this sense, treaty outcomes would reflect not only the preferences of negotiating governments but also those of all ratifying actors. In the case of parliamentary ratifications, it all depends on the type of majority required, which in some cases is simple majority and in other cases qualified majority. It may at times happen that national governments defend the common proposal while opposition forces for domestic reasons criticise the suboptimal outcome for their country (König 2006; König and Finke 2007). In the case of referendums, empirical evidence is not convergent, which means that the effectiveness of this source of power may be contingent upon the bargaining environment (Hug and König 2002; König and Slapin 2006). ${ }^{13}$ Moreover, a referendum might lead to gains, but only if it is scheduled in a country with euro-sceptical voters. In case of 'ratifications accidents', the re-negotiations would result in marginal changes, if any at all (Hug and Schultz 2007).

Going beyond static interest-driven explanations, from a constructivist perspective it is argued that the process of treaty reform is influenced by the presence of detailed rules and established practises. Preference formation is not exogenous but is affected by the interaction between actors and their environment. ${ }^{14} \mathrm{EU}$ membership matters and it

\footnotetext{
10 In this sense, Reh (2007) and Puetter (2007) respectively look the impact of the Group of Government Representatives and of the finance ministers on treaty negotiations. It should be however noted that Reh does not explore the degree of independence of national delegates from capitals.

11 A major contribution to understanding the link between domestic politics and treaty reform has been given from the DOSEI project, a group of researchers dealing with 'domestic structures and European integration', though their analysis is mostly limited to the Constitutional Treaty.

12 The most controversial issue during the negotiations for the Constitutional Treaty concerned the proposal to reduce the size of the Commission - smaller Member States feared that they would lose importance - and to modify the voting threshold in the Council - Poland and Spain feared to become less powerful (Slapin 2008; König and Slapin 2006).

13 The nature of the Convention itself, which required consensus and not unanimity and the lack of information about the ratification process may have been more important - the negative outcome in France and the Netherlands is thus explained (König and Slapin 2006).

${ }^{14}$ The impact of domestic politics on European integration has generally been inadequately dealt with by constructivism. Two typical constructivist topics - such as socialisation and identity - demonstrate however that the link between domestic politics and the EU plays a role in the European integration (Checkel 2007:67-70). For instance, Hooghe (2005) shows that identity change and socialisation within the European Commission is a product of national socialisation. Risse (2005) argues that the various components of an individual's identity cannot be separated, but actually its different components (national and European) are interlinked.
} 
does so for various reasons: it may generate a socialisation effect; it may lead to consensual agreements; it may help derive lessons from past experience. This means that preferences are not always 'national' in origin, but can be (re)shaped between two, or even during, IGCs (Falkner 2002; Christiansen, Falkner and Jørgensen 2002). In fact, "governments bring some options from home, put them next to which they have agreed on among the fifteen governments ... and confront them with preferences expressed by the EU institutions" (Falkner 2002: 3). Moreover, the fact that new treaties are amended versions of previous treaties "constitutes a slippery slope towards incremental adaptation of already institutionalised patterns of behaviour" (Christiansen, Falkner and Jørgensen 2002: 16). Time plays a central role: this includes not only election cycles at the national level, but also the setting of roadmaps and the imposition of deadlines by individual Presidencies, which result in a sort of 'all or nothing' situations. Preference formation does not always precede bargaining, but it is often intermingled with bargaining (Christiansen, Falkner and Jørgensen 2002). Treaty reform, therefore, rather than a 'two-level game' is a 'three-level process': that is, "a social process that can change preferences, interest and identities", which includes not only the domestic and the EU levels, but also a "European cobweb of EU-specific institutions (like the Commission and the EP) as well as procedural patterns and norms (EU-level institutions in a wider sense)" (Falkner 2002: 2). ${ }^{15}$

\section{The road to the Treaty of Lisbon}

The road to Lisbon commenced in December 2001 when the European Council in Laeken established the Convention on the Future of Europe (see table 1). The Convention produced a 'Draft Treaty Establishing a Constitution for Europe', which was submitted to the European Council in July 2003. Negotiations in the IGC started in October 2003. Despite an initial strong opposition by Spain and Poland, which wanted to preserve the advantageous voting system obtained in Nice, a slightly modified text what became known as the Constitutional Treaty - was signed in October 2004 by the 25 heads of state and government in Rome, but under the Irish Presidency. The change of government in Spain, with the new socialist government taking a more conciliatory approach, was central to end the impasse, not least because it isolated Poland.

The main innovations introduced by the Constitutional Treaty, which eventually became contentious in the negotiation of the Treaty of Lisbon, concerned the EU's institutional framework. First, a new 'double majority' was introduced for voting in the Council: decisions made using the QMV would pass if supported by $55 \%$ of the Member States, representing $65 \%$ of the EU's population. Furthermore, the use of the QMV would be applied to a larger number of policy areas, especially in matters related to police and judicial cooperation. Second, the size of the College of Commissioners would be reduced to two-thirds of the number of Member States. This cut would be based on a system of 'strictly equal rotation'. Third, the role of the European Parliament would be enhanced as a result of the extension of policy areas covered by the codecision procedure, including agriculture and home affairs. The co-decision procedure would become 'the ordinary legislative procedure'. Fourth, to help ensure policy continuity and to enhance the EU's role in the international arena, the rotating Presidency would be replaced by a team of members to operate for 18 months. The President of the Union would be elected by the Member States for a term of 30 months, renewable once. Fifth, a new post, the European Foreign Minister, would be created by merging the posts of High Representative for the Common Foreign and Security Policy (CFSP) and Commissioner for External Relations; this new double-hat actor would chair the Foreign Affairs Council and act as the Vice-President of the Commission.

\footnotetext{
15 Another interesting insight comes from the case of the referendum. The high number of referendums in the case of the Constitutional Treaty may also be part of a sort of 'Europeanisation of the ratification process', through which some governments under domestic pressure decided to copy neighbour countries (Konig, Daimer and Finke 2008).
} 
Table 1: Key dates in the road to the Treaty of Lisbon

\begin{tabular}{|c|c|}
\hline Date & Event \\
\hline 14-15 Dec 2001 & $\begin{array}{l}\text { The European Council at Laeken adopts a 'Declaration on the } \\
\text { Future of Europe' and establishes the Convention on the Future of } \\
\text { Europe to prepare a comprehensive reform of the EU Treaties. }\end{array}$ \\
\hline 28 Feb 2002 & The Convention holds its inaugural meeting \\
\hline $18 \mathrm{Jul} 2003$ & $\begin{array}{l}\text { The Convention submits a 'Draft Establishing a Constitution for } \\
\text { Europe' to the President of the European Council in Rome }\end{array}$ \\
\hline 4 Oct 2003 & $\begin{array}{l}\text { The IGC is launched to consider the draft submitted by the } \\
\text { Convention }\end{array}$ \\
\hline 18 Jun 2004 & $\begin{array}{l}\text { The Constitutional Treaty is agreed by heads of state and } \\
\text { government }\end{array}$ \\
\hline 29 Oct 2004 & $\begin{array}{l}\text { The Constitutional Treaty is signed by heads of state and } \\
\text { government in Rome. }\end{array}$ \\
\hline 29 May-1 Jun 2005 & $\begin{array}{l}\text { The referendums to ratify the Constitutional Treaty held first in } \\
\text { France and then in the Netherlands give negative results }\end{array}$ \\
\hline 16 Jun 2005 & $\begin{array}{l}\text { The European Council calls for a 'pause of reflection' to last one } \\
\text { year }\end{array}$ \\
\hline 15-16 Jun 2006 & $\begin{array}{l}\text { The European Council asks the upcoming German Presidency to } \\
\text { present a report on how to end the constitutional deadlock }\end{array}$ \\
\hline 25 Mar 2007 & $\begin{array}{l}\text { The Berlin Declaration, adopted by heads of states and } \\
\text { government to celebrate the } 50^{\text {th }} \text { anniversary of the EU, calls for a } \\
\text { new treaty to be in place by } 2009 \text {. }\end{array}$ \\
\hline $21-22$ Jun 2007 & $\begin{array}{l}\text { The European Council agrees on a mandate for the IGC to finalise a } \\
\text { 'Reform Treaty' }\end{array}$ \\
\hline $23 \mathrm{Jul} 2007$ & The IGC is launched \\
\hline $18-19$ Oct 2007 & The Treaty of Lisbon is agreed by heads of state and government \\
\hline 13 Dec 2007 & $\begin{array}{l}\text { The Treaty of Lisbon is signed by heads of state and government in } \\
\text { Rome. }\end{array}$ \\
\hline 12 June 2008 & $\begin{array}{l}\text { The referendum to ratify the Treaty of Lisbon held in Ireland gives } \\
\text { negative results }\end{array}$ \\
\hline 11-12 Dec 2008 & $\begin{array}{l}\text { The European Council reassures Ireland, which in return commits } \\
\text { to hold a new referendum by the end of } 2009\end{array}$ \\
\hline
\end{tabular}

Source: Europa Website. Available at: http://europa.eu/

While many Member States decided to proceed to parliamentary ratification, a significant number of countries announced that they would use the referendum as their ratification tool. The negative outcome of the 2005 referendums in France and in the Netherlands, whose populations have traditionally been among the most supportive of European integration, was seen as a crisis of legitimacy and even a triumph of euro-scepticism in European societies. One of the ways to explain this failure is to look at the workings of the Convention: the new format may have achieved more than traditional IGCs, but it overlooked the preferences of all ratifying actors (König and Hug 2006).

Following the rejections of the Constitutional Treaty, the Member States decided to take a 'period of reflection'. This pause was initially meant to last one year, but at the European Council in June 2006 leaders simply agreed that a solution to the constitutional deadlock would have to be found by the end of 2008 at the latest, with great hopes being pinned on the upcoming German Presidency to relaunch the constitutional debate (European Report 19 June 2006). A clear division emerged between the 'maximalist group' that had ratified the Constitutional Treaty, 18 countries in total including two by referendums (Spain and Luxembourg), and the 'minimalist group' that had either rejected it (France and Netherlands) or postponed/suspended the planned referendum to ratify it (Czech Republic, Denmark, Ireland, Poland, Portugal, 
Sweden, United Kingdom) (see table 2). ${ }^{16}$ These divergences became more evident when Spain and Luxembourg convened a meeting of the maximalist group plus Portugal and Ireland - which became known as the 'Friends of the Constitution' - in Madrid in January $2007 .{ }^{17}$ In response to the proposal made by the French presidential candidate, Nicolas Sarkozy, who had advanced the idea of a 'mini-treaty', they called for a 'maxi-treaty', which would keep as much of the Constitutional Treaty as possible (Financial Times 27 January 2007; European Report 30 January 2007). Interestingly, a few leaders in this camp (for instance Belgian Prime Minister Guy Verhofstadt and Italian Prime Minister Romano Prodi) even launched the idea of an avant-garde group of Member States to drive forward European integration (European Report 24 April 2007; European Report 24 May 2007).

The minimalist group, by contrast, wanted to introduce only some amendments to the Treaty of Nice. The United Kingdom raised a number of issues (the famous red lines) that needed to be preserved in the negotiations of any new treaty: preservation of the UK's existing labour and social legislation; protection of the UK's common law system and police and judicial processes; maintenance of the UK's independent foreign and defence policy; protection of the UK's tax and social security system. For Poland, the main issue was the voting system, which in their view gave too much power to Germany and penalised medium and small-sized Member States (The Times 20 June 2007). The Czech Republic and the Netherlands (as well as Poland), teamed up to call for a new mechanism that allowed a group of governments to request power to be returned to Members States from the EU, a sort of enhanced cooperation in reverse (European Voice 16 May 2007).

The debate restarted in early 2007 under the German Presidency. In her inaugural speech at the European Parliament, Chancellor Angela Merkel made clear that not only was the pause for reflection over, but also that the German Presidency would engage in a "series of confidential consultations to learn what is possible in the member states" (European Report 18 January 2007; Financial Times 18 January 2008). Chancellor Merkel and two 'sherpas' started the consultations with their counterparts in the Member States, with the aim to resolve most of contentious issues in the context of the European Council in June 2007. The ultimate aim was to agree on a new treaty before the European Parliament elections in June 2009. The informal summit of European leaders held on the occasion of the $50^{\text {th }}$ anniversary celebrations of the EU in March 2007 showed that the differences between the minimalist and maximalist groups persisted. The Berlin Declaration contained a vague appeal to re-launching the constitutional process - "placing the European Union on a renewed common basis before the European Parliament elections in 2009" (European Report 27 March 2007) but not much more. The fact that it was signed only by the representatives of the three EU institutions - Council, Parliament, and Commission - confirmed the existence of disagreements among Member States on how to proceed (Time 26 March 2007; Financial Times 26 March 2007).

The national elections in France and in the Netherlands brought important changes. In France, Sarkozy won the elections held on 6 May 2007 with a large majority, which gave him a large degree of manoeuvre in the debate on the EU constitutional deadlock. The new President not only emphatically proclaimed that France was 'back in Europe', but

\footnotetext{
${ }^{16}$ To be fair, the United Kingdom, Poland and the Czech Republic were the staunchest opponents to a return to the Constitutional Treaty. The elites of France and the Netherlands could not take a clear position before new elections were held.

${ }_{17}$ A statement was released indicating that: a) only a politically united Europe can play a key role in the globalised world; $b$ ) the Constitutional Treaty, which was the product of difficult negotiation and a fragile balance, would enable the EU to act more effectively; c) the Group is willing to accept a compromise, with a view to come to an agreement that safeguards the substance of the Constitutional Treaty; d) the Group supports the efforts of the German presidency (European Report 29 January 2007).
} 
turned its initial ideas of a 'mini-treaty', which was too evocative of British minimalism, into a 'simplified treaty'. Moreover, he added that, should no 'European Constitution' was adopted, a parliamentary ratification would be sufficient for an amending treaty in contrast to the Socialist candidate who had promised a referendum (Le Monde 7 May 2007; European Report 11 May 2007; Financial Times 4 June 2007). In a similar vein, the change of government in the Netherlands, following the November 2006 elections, had an impact on the EU's reform process. The new Prime Minister Jan Peter Balkenende announced that his government would have a 'constructive position' on the European constitutional process. In a meeting with Tony Blair, he proposed revisions to the existing Treaty of Nice, but along the lines of the rejected Constitutional Treaty (European Report 25 May 2007). As for the United Kingdom, British diplomats had identified a number of issues, particularly sensitive to their public, to be subtracted from the Constitutional Treaty. This would give the national audience a sense of a 'battle won', and would make a referendum, whose positive result could not be anticipated, no longer necessary, and at the same time would not jeopardise the agreement of a new treaty (The Guardian 18 June 2007). The pessimistic views coming from the bilateral meetings held by German diplomats with their European counterparts and a first meeting of all 27 representatives in Berlin on 15 May - where the impression among observers was that the EU would need to step back from its lofty ambitions (European Voice 24 May 2007) - were rapidly changing as a result of these evolutions in the domestic politics of various Member States. A compromise seemed to emerge towards the end of the German Presidency: between the 'maxi-treaty' and the 'mini-treaty', the new consensus was for a 'simplified treaty', which preserving the spirit of the Convention would take into account the domestic concerns of the minimalist group (Dinan 2008).

The biggest stumbling block in the negotiations remained Poland. Its main problem was still the issue of the double majority voting. In an attempt to address this problem, the Polish government proposed a new system, based on the square root of the number of inhabitants (in million) for each Member State (Financial Times 12 June 2007). In contrast to the British red lines, the issue of voting was at the heart of the EU decision making process; many Member States, thus, were not inclined to meet the Polish demands. The words of the Prime Minister Jaroslaw Kaczyński left little to the imagination: "I want to stress clearly that we are taking our proposal of the square root in the most serious manner possible. We are prepared to die for it, despite information to the contrary in the press" (European Report 1 June 2007). This battle reflected the views of a majority of members of the Polish Parliament, which adopted a resolution in support of the government seen as defending a vital issue (European Report 20 June 2007). The Polish government received also support from the Czech government, "more out of an attachment to the logic of an awkward squad than on true commitment" (European Report 14 June 2007). In fact, Prague was more favourable to a revision of the voting system introduced by the Constitutional Treaty with the aim to reduce the gap between large and small states, rather than the square root formula per se.

Most of these issues were dealt with at the European Council of 21-22 June 2007. Various concessions were granted to the recalcitrant Member States. The British government worked cooperatively, often behind the scenes, and secured all its red lines, including a derogation from the Charter of Fundamental Rights and further optout possibilities on Justice and Home Affairs. The Netherlands saw the role of national parliaments and citizen participation strengthened, as well as the introduction of a protocol stressing the importance of services of general interest. ${ }^{18}$ Sarkozy convinced other leaders that 'free and undistorted competition' should not be included among

\footnotetext{
18 It was established that 'one million citizens who are nationals of a significant number of member states' can ask the European Commission to submit a proposal on a matter that falls within its competences. National parliaments will become more involved in the legislative process. They have to be notified of proposed legislation and have eight weeks to deliver their comments.
} 
the EU's objectives - an additional protocol was however added to make it clear that the internal market would not be affected. Poland tried to resist any change, but eventually had to accept the principle of the double majority voting, though it managed to secure agreement that the new voting system would not enter into force before 2014 and would be gradually phased in over three years to be fully implemented by 2017. ${ }^{19}$ Moreover, it was agreed that the loannina compromise, which facilitates the constitution of a blocking minority whilst avoiding a veto, might be used immediately. ${ }^{20}$ Smaller Member States accepted the principle of the rotation, but it was decided that the European Council, acting unanimously, could alter the number of Commissioners, which leaves the door open to a larger European Commission in the future (The Guardian 22 June 2007; Le Monde 23 June 2007; The Times 23 June 2007). At the end, Member States agreed to convene a new IGC, which would operate under a mandate and 'complete its work as quickly as possible'. The strict mandate for what was initially called the Reform Treaty, included: eliminating all statist and constitutional symbols; excluding the Charter of Fundamental Rights (and the primacy of EU law) from the main body of the treaty; finding a new name for the EU Foreign Minister; keeping directives, regulations, and decisions as the EU's legislative acts rather than introducing the proposed laws and framework laws (Financial Times 25 June 2007; European Voice 26 June 2007). The agreement of a strict mandate was somewhat a novelty in the EU, but was meant to speed up negotiations. In sum, this compromise seemed to many "to be a mixture of meeting possible ratification difficulties and keeping the substance of the original reform" (König, Daimer, and Finke 2008: 342).

The IGC operated between July and October 2007. However, most of the work was done by legal experts, who redrafted the text according to the mandate of the June 2007 European Council. In view of the European Council to be held on $18^{\text {th }}-19^{\text {th }}$ October, Poland and Italy, driven by domestic politics concerns, raised last minute problems. Unexpectedly, early elections were called in Poland for $21^{\text {st }}$ October. The Polish government, under pressure because of the negative predictions on the outcomes of the elections, tried to re-open the debate on the voting system, asking for the inclusion of the loannina compromise in the main text of the Treaty (Financial Times 19 October 2007). This request was rejected, but Poland was compensated with a reinforced energy solidarity clause - it was established that the EU 'shall acts in a spirit of solidarity' if any of its members is a victim of an energy supply problem or other natural or man-made disasters - and with a permanent advocate-general in the European Court of Justice (ECJ), in line with the other big five countries. ${ }^{21}$ Italy was unhappy with the redistribution of seats in the new European Parliament: it accepted the reduced number (from 78 to 72), but not the lost parity with France (74) and the United Kingdom (73) on the basis of number of residents rather than citizens. Italy did eventually receive an extra seat, but to maintain the ceiling of 750, it was decided that the President would not be counted (Corriere della Sera 18 October 2007; II Sole 24 Ore

\footnotetext{
${ }^{19}$ The relations between Poland and Germany during the summit were tense. The situation worsened significantly when the Polish leaders attempted to justify the new proposal as a way to counter Germany's voting power. Then, the Prime Minister said that a new population-based voting formula was unfair because it did not take into account the fact that Poland had lost tart of its population during the Second World War II. The German Chancellor threatened to exclude Poland from the IGC if it maintained these positions. A central role was played by Sarkozy, who in concert with Merkel, took the initiative of holding private talks with the Polish Prime Minister and President. Sarkozy was assisted by the Prime Ministers of the United Kingdom, Spain and Luxembourg (Financial Times 22 June 2007; The Times 22 June 2007; EurActiv 23 June 2007; European Voice 28 June 2007).

20 The loannina compromise stipulates that if there are no sufficient votes to constitute a blocking minority, but $75 \%$ of the number of countries or $75 \%$ of the population necessary to constitute a blocking minority, the issue is to be referred back to the Council for further discussion. An agreement should be reached within 'reasonable time'.

${ }^{21}$ It was established to create two additional advocates-general to be assigned to the remaining 21 Member States, which will therefore be able to appoint an advocate-general on a rotating basis every 24 years (European Report 22 October 2007).
} 
19 October; European Report 22 October 2007). ${ }^{22}$ Once all these issues were solved, the next step was the adoption of the Treaty of Lisbon in the capital of Portugal on 13 December 2007 by all the EU's heads of state and government.

Table 2: Ratifications of the Constitutional Treaty and the Treaty of Lisbon

\begin{tabular}{|c|c|c|c|c|}
\hline & \multicolumn{2}{|c|}{ Lisbon Treaty } & \multicolumn{2}{|c|}{ Constitutional Treaty } \\
\hline & Method & Date & Method & Date \\
\hline Austria & Parl & 09 Apr 2008 & Parl & $\begin{array}{l}11 \text { May } 2005 \\
25 \text { May } 2005\end{array}$ \\
\hline Belgium & Parl & $\begin{array}{c}05 \text { Mar } 2008 \\
10 \mathrm{Jul} 2008 \\
\end{array}$ & Parl & $\begin{array}{l}28 \text { Apr } 2005 \\
08 \text { Feb } 2006\end{array}$ \\
\hline Bulgaria & Parl & 21 Mar 2008 & Parl (Acces) & 11 May 2005 \\
\hline Cyprus & Parl & 03 Jul 2008 & Parl & 30 Jun 2005 \\
\hline Czech Rep & Parl & Pending & Ref & Not held \\
\hline Denmark & Parl & 24 Apr 2008 & Ref & Not held \\
\hline Estonia & Parl & 11 Jun 2008 & Parl & 09 May 2006 \\
\hline Finland & Parl & 11 Jun 2008 & & 05 Dec 2006 \\
\hline France & Parl & $\begin{array}{l}\text { 07 Feb } 2008 \\
08 \text { Feb } 2008\end{array}$ & $\begin{array}{c}\text { Ref } \\
\text { Not approved }\end{array}$ & 29 May 2005 \\
\hline Germany & Parl* & $\begin{array}{l}24 \text { April } 2008 \\
23 \text { May } 2008 \\
\end{array}$ & Parl & $\begin{array}{l}12 \text { May } 2005 \\
27 \text { May } 2005 \\
\end{array}$ \\
\hline Greece & Parl & 12 Jun 2008 & Parl & 19 Apr 2005 \\
\hline Hungary & Parl & 17 Dec 2007 & Parl & 20 Dec 2004 \\
\hline Ireland & Ref & Not approved & Ref & Not held \\
\hline Italy & Parl & $\begin{array}{l}23 \mathrm{Jul} 2008 \\
31 \mathrm{Jul} 2008 \\
\end{array}$ & Parl & $\begin{array}{l}25 \text { Jan } 2005 \\
06 \text { Apr } 2005\end{array}$ \\
\hline Latvia & Parl & 8 May 2008 & Parl & 01 Jun 2005 \\
\hline Lithuania & Parl & 8 May 2008 & Parl & 11 Nov 2004 \\
\hline Luxembourg & Parl & 29 May 2008 & Ref & 10 Jul 2005 \\
\hline Malta & Parl & $06 / 02 / 08$ & Parl & 06 Jul 2005 \\
\hline Netherlands & Parl & $\begin{array}{c}05 \text { Jun } 2008 \\
08 \text { Jul } 2008\end{array}$ & $\begin{array}{c}\text { Ref } \\
\text { Not approved }\end{array}$ & 01 Jun 2005 \\
\hline Poland & Parl* & $\begin{array}{l}\text { 01 Apr } 2008 \\
\text { 02 Apr } 2008\end{array}$ & Ref & Not held \\
\hline Portugal & Parl & 23 Apr 2008 & Ref & Not held \\
\hline Romania & Parl & 4 Feb 2008 & Parl (Acces) & 17 May 2005 \\
\hline Slovakia & Parl & 10 Apr 2008 & Parl & 11 May 2005 \\
\hline Slovenia & Parl & 29 Jan 2008 & Parl & 01 Feb 2005 \\
\hline Spain & Parl & $\begin{array}{c}26 \text { Jun } 2008 \\
15 \text { Jul } 2008\end{array}$ & $\begin{array}{l}\text { Ref } \\
\text { Parl }\end{array}$ & $\begin{array}{l}20 \text { Feb } 2005 \\
28 \text { Apr } 2005 \\
19 \text { May } 2005\end{array}$ \\
\hline Sweden & Parl & 20 Nov 2008 & Ref & Not held \\
\hline United Kingdom & Parl & 18 Jun 2008 & Ref & Not held \\
\hline
\end{tabular}

Source: Europa Website. Available at: http://europe.eu/

N.B. This table is updated to December 2008. * In Germany and in Poland the Treaty needs to be signed off by the President

But to come into force, the Treaty of Lisbon needed to be ratified by all Member States. In contrast to the Constitutional Treaty when ten countries decided to refer the issue back to the people, in this case Ireland, in line with what is written in the Irish Constitution, was the only country to choose a referendum (see table 2 above). The process of ratification started already in December 2007 with Hungary being the first Member State to ratify it with an overwhelmingly majority in the parliamentary vote. A

\footnotetext{
22 In addition, Austria managed to set quotas for foreign students, with particular reference to their medical faculties inundated with German students. Bulgaria was acknowledged the right to Cyrillic spelling of the word euro, which had been resisted by the European Central Bank.
} 
large number of Member States - 18 in total - had already ratified the Treaty of Lisbon when on 12 June 2008 the referendum was held in Ireland. The Irish voters voted by $53.4 \%$ to $46.6 \%$ (of roughly half of the population who went to vote) against ratification. This outcome, described by some as 'a shock' for European integration and by others as 'a triumph of democracy', risked to have a 'contagion' effect across Europe (Financial Times 13 June and 18 June 2008; Irish Times 19 June 2008). Analysis of the vote showed that there was not a single reason for voting No, but a 'motley selection of grumbles' (EUobserver 16 June 2008). In addition to the lack of adequate information, various fears were cited, notably: rise in corporate tax, protection of workers' rights, neutrality in the international arena, potential introduction of legislation on abortion, loss of a commissioner. The European Council that met on 19-20 June 2008 discussed the result of the Irish referendum and decided that more time was needed to find a way forward (EurActiv 25 June 2008). The French Presidency, which took over in July 2008, urged other Member States to continue with the ratification process, stating that any further EU enlargement could not take place until the Treaty of Lisbon came into force (The Guardian 20 June 2008).

By the end of 2008, all countries had fully ratified the Treaty of Lisbon but four: Ireland, the Czech Republic, Germany, and Poland. In Germany, a member of the Christian Social Union (CSU) and the party of the Left, Die Linke, had taken the Treaty to the Constitutional Court; they accused it of respectively creating a federal European state and abolishing the German social state. In Poland and in the Czech Republic, eurosceptical leaders used the outcome of the Irish referendum as a scapegoat to delay the process of ratification: in the first case, President Lech Kaczyński refused to sign off the Treaty despite the approval of the Parliament; in the second case, once the Czech Constitutional Court had established that the Treaty was not unconstitutional, the government under pressure from the opposition accepted to postpone the discussions until February 2009 (EurActiv 25 July 2008; Financial Times 27 November 2008). Meanwhile, the European Council on 11-12 December 2008 adopted a declaration reassuring Ireland that areas of particular concern for its population (i.e. taxation policy, family, social and ethical issues and the foreign policy) would be safeguarded and that it would also retain the right to send a commissioner to Brussels. In return, Irish leaders committed to holding a new referendum in autumn 2009 (Financial Times 13 December 2008).

\section{Preference Formation and Inter-state Bargaining}

The Treaty of Lisbon returned to the practice of amending treaties. Rather than replacing (which was the logic behind the Convention) the Treaty of Lisbon amends both the Treaty on the European Union and the European Community Treaty, which becomes the Treaty on the Functioning of the European Union. As mentioned above, numerous concessions were granted to several Member States. In a majority of cases, demands were clearly driven by domestic concerns, such as new leadership, elections, and fear of the referendum. In other cases, the context, such as the presence of a draft as a starting point and the desire to end the institutional crisis as quickly as possible, played a significant role. This section concentrates on four issues, in line with what was discussed in the theoretical section of the paper: actors, political system, ratification hurdles, and EU membership..$^{23}$

\footnotetext{
${ }^{23}$ This section substantially benefits from the reading of a number of papers which are going to be included in a book that I have edited on 'National Politics and European Integration: From the Constitution to the Lisbon Treaty' (Carbone 2010 forthcoming). In particular, I have drawn from the chapters written by Thomas Christiansen on the overall reform process, Simon Bulmer on Germany, Helen Drake and Christian Lequesne on France, Neill Nugent and David Phinnemore on the United Kingdom, Lucia Quaglia on Italy, Paul Lewis on Poland, Mary Farrell on Spain and Portugal, Brian Girvin on Ireland, Karen Henderson on the Czech Republic and Slovakia, Peter Bursens and Ben Crum on the Benelux countries.
} 
First, national governments did play a central role in the preparatory process and the negotiations, yet various other actors constrained their choices. In Italy, the opposition and the media significantly affected the stance taken by the Prodi government in the final stages of the negotiations when a plan to reduce the number of MEPs was seen as penalising Italy vis-à-vis other big European states, notably the United Kingdom and France. In Poland, before the European Council in June 2007 the Parliament passed a resolution supporting the government in its efforts to defend what was perceived as a vital issue; that is, the voting threshold. But sources outside governmental circles expressed a different opinion: the alternative views coming from a part of the academic world in response to the square root formula and the growing popular support for the European Union contributed to mollify the aggressive stance taken by the government in Brussels. In the United Kingdom, grassroots euro-scepticism increased beyond the Conservative Party and popular media. The government therefore designed the red lines to be seen by the domestic opposition as fighting for the national interest. In the two countries that had rejected the Constitutional Treaty, the governments tried to minimise any potential problem coming from opposition parties and societal groups. In France, while the EU's constitutional deadlock was a salient issue in the electoral campaign, following the May 2007 national elections the new President, legitimated by a sound victory against the Socialist candidate (who incidentally had proposed a referendum in the event of a new EU treaty), managed to silence the debate, also taking advantage of the inability of the various opposition parties to establish a united front. ${ }^{24}$ In the Netherlands, the new government that came out from the November 2006 elections successfully managed to reclaim the EU issue from political parties and public opinion to return to the traditional 'national' position of loyal state to European integration.

More actors were involved at the ratification stage. In Germany, criticisms came from the Left parties, which argued that the Treaty was undemocratic, neo-liberal and militaristic, and from a member of one of the ruling parties, the Christian Social Union, who argued that the Lisbon Treaty was incompatible with the German Basic Law. These challenges were taken to the Federal Constitutional Court (FCC), which meant that the President of the Republic could not sign off the Treaty, despite approval by the Parliament with an overwhelming majority (515 votes to 58$){ }^{25}$ In Poland, the government had to deal with an antagonistic President of the Republic rather than with the opposition in the Parliament. President Kaczyński, following the Irish referendum, stated that it would be pointless to sign the Treaty (despite the earlier approval by the Parliament), defined as an useless document that would not further Poland's interests. The views of the President reflected the position of his own party, chaired by his twin brother, which was in the opposition after the October 2007 elections. Something similar occurred in the Czech Republic where President Klaus took advantage of the Irish referendum to state that ratification could not continue; moreover, a group of senators belonging to one of the parties in the ruling coalition took the Treaty of Lisbon to the Constitutional Court to verify its constitutionality. Despite the fact that the Constitutional Court, on 26 November 2008, ruled that the Treaty was not unconstitutional, at the insistence of the opposition the government accepted to postpone any decision on ratification until February 2009.

Second, the political system and domestic structures had an important impact on preference formation and inter-state bargaining in a number of ways. The change of government determined a shift of approach in Italy and Spain. In both cases, while in the road to the Constitutional Treaty the two new centre-right governments had taken a lukewarm approach, in the road to the Treaty of Lisbon the centre-left governments

\footnotetext{
${ }^{24}$ This obviously does not mean that the French Parliament does not exercise any role in matters related to the EU. In fact, since Maastricht French parliamentarians have enhanced their scrutiny of EU policy making.

${ }^{25}$ It should be noted that in the case of the Treaty of Lisbon, the Länders did not play a significant role as they had done in other treaties (for instance in the Treaty of Nice ).
} 
were part of the Friends of the Constitution group, with Spain in a leading position. Nevertheless, the administrative ethos within both ministries of foreign affairs ensured some continuity in face of the change of attitudes of governments. In France, the change of direction was linked more to the election of a new President, who in fact belonged to the same party of his predecessor. Paradoxically, more continuity was seen in the United Kingdom: the Labour government tried to minimise political and popular press accusations of 'selling out' to integrationists and opening the road to a sort of European federation. By obtaining a number of opt-outs, it behaved not much differently from the way in which the Conservatives had operated in the past; in fact, it would be difficult to imagine the Conservatives conducting negotiations any differently. In the case of the Treaty of Lisbon, it could be said that European policy for the UK looked more bipartisan than ever. In Poland, the weak and fragmented government and the peculiar nature of leadership - with the Kaczyński twins playing the role of Prime Minister and President of the Republic - affected the articulation of the Polish positions, which on the one hand needed to be aggressive so as to be seen to be defending the national interest and on the other hand was facing internal clashes between two politically eccentric parties and the Kaczyński twins.

In light of the particular situation (i.e. the presence of a text as a starting point), it is not surprising that in many countries preference formation concentrated on the head of the executive. In France, the close collaboration between the President and his advisors on the one hand, and between the Foreign and Europe Ministers on the other hand contribute to explaining the success of the 'French team' in persuading some of the most recalcitrant Member States. In Germany, the Chancellor played a central role, bypassing standard practises, which would have normally centred on the Foreign Ministry. In most countries in Central Europe, including Poland and Czech Republic, the weak and fluid party system and its tenuous and largely institutionalised link with the electorate gave considerable scope for personality politics and changes of political positions in the approach to Europe. The tendency is for lobbying to take place within parties, where clientelistic interests interact with programmatic orientations. In a number of countries, such as for instance Portugal, Belgium, and Luxembourg, just to mention some of the Friends of the Constitution, no serious domestic cleavages existed on the Treaty of Lisbon. In Spain, the Socialist government and main opposition party shared the view that a new Treaty should be adopted as quickly as possible and retain the substance of the Constitutional Treaty - interestingly the leader of the Partito Popular Mariano Rajoy rejected a suggestion from his predecessor José Maria Aznar to take a more critical stance on the new Treaty.

Third, ratification hurdles affected preference formation and the strategies adopted by various Member States in the negotiations as well as the final outcome. To guarantee a smooth ratification process and to prevent the risk of the referendum, several controversial issues were subtracted from the starting point, the Constitutional Treaty. These included not only the symbolic elements (i.e. flag, anthem, motto), but also various other issues at the request of one or a group of Member States. In France, Sarkozy claimed that the excessive neo-liberal dimension of the new Europe was one of the key reasons behind French voter rejection of the Constitutional Treaty. The much publicised removal of 'free and undistorted competition' from the EU's objectives, but more significantly the protocol emphasising the importance of 'services of general interest' as un underlying value of the EU and the general principle that the EU had to 'protect its citizens' represented an indirect recognition of the limits of market competition. The Netherlands identified the strengthening of the democratic component of the new treaty - by increasing the space for citizens' initiatives, ensuring a greater role for national parliaments, reinforcing the role of the European Parliament in monitoring the application of the subsidiarity principle - as the main answer to the Dutch public opinion concerns about the EU's democratic deficit.

The fear of a failed referendum was used by the British government, which asked for guarantees about its continuing independence and sovereignty in certain policy areas: 
labour and social legislation; tax and social security; common law system and police and judicial processes; foreign and defence policy. The case of Ireland shows that failing to take into account the ratification hurdles resulted in a delay of the overall reform process. Not only is there little evidence that the Irish government used the referendum as a bargaining tool at the EU negotiating table, but it also seems to have discounted the negative experience of referendum on the Treaty of Nice. Other countries raised vital issues during the negotiations to receive concessions. Poland, in an attempt to maintain the status quo, resisted the change of the threshold for qualified majority voting in the Council - its Prime Minister even said he was ready to die for the new square root formula. Early elections on the eve of the decisive meeting in October 2007 hardened even more these positions. Some extra concessions - an energy solidarity clause and a permanent advocate-general in the ECJ - contributed to appeasing the Polish government. ${ }^{26}$ The Italian government, which had been among the staunchest supporters of a maximalist treaty, threatened to delay the agreement on the eve of the October 2007 European Council: the loss of parity with the United Kingdom and France was perceived by various domestic actors as a vital issue.

Finally, the context is also important to understand policy outcome. Preference formation is not entirely endogenous, but contingent historical choices may lock in Member States and shape their preferences. Taking into account the context means also that there is a general preference for EU solutions when no specific national interest is at stake. The existence of the Constitutional Treaty as a point of departure, the acceptance of the 'strict mandate' chosen by the German Presidency to secure a new treaty, the speed to which events moved in 2007 - with almost all deals agreed between June and October 2007 - constituted a remarkable constraint on (many) Member States. For instance, a number of the British requests as well as most of the demands of Poland, Czech Republic and the Netherlands were accepted by the Friends of the Constitutions because they wanted to see the negotiation process conclude quickly. In this sense, the desire to end the crisis and devote more energy to more pressing issues, such as the economic crisis and the budget negotiations, explains the positions taken by countries like Belgium, Luxembourg, Spain, Portugal. In the case of Portugal and Germany, preferences were shaped by the fact they held the Presidency. In particular, Chancellor Merkel pursued a pragmatic approach, much in line with the circumstances, but far from the visionary stances of past German leaders. The office of the Presidency held when the Constitutional Treaty was finalised shaped the preferences and behaviour of the Irish government and ultimately contributes to explaining why the Irish government failed to ask for concessions when the Lisbon Treaty was finalised.

\section{Conclusion}

The European Union has been attempting to reform its institutional framework since the early 2000. This process started with the speech pronounced by the German Foreign Minister Joschka Fischer at Humboldt University, even before the Treaty of Nice was signed. It continued with a constitution building process, which resulted in a Constitutional Treaty proposed by the Convention on the Future of Europe in July 2003, broadly accepted and then signed by the Member States in October 2004, but eventually rejected by the French and Dutch citizens in May-June 2005. The Convention in reality was less than the 'deliberative forum' that many expected, but more or less largely reflected the positions of the various Member States. Nevertheless, it failed to take into account the potential problems coming from the ratification process. The work of the Convention and the adoption of the Constitutional Treaty has been the object of an extensive debate among scholars. For this reason, this article starting from the referendum held in France, aimed to analyse the preparation,

\footnotetext{
${ }^{26}$ A number of countries - Netherlands and France, with the implicit support of Austria and Germany tried to include the Copenhagen criteria for enlargement into the Treaty, but did not succeed.
} 
negotiation and ratification of the Treaty of Lisbon, signed in December 2007 and eventually rejected by the Irish citizens in June 2008.

The road that took to Lisbon shows that taking into account domestic politics is essential to better understanding treaty reform in the EU. Going beyond the view that national governments are the sole driving force in the grand bargains of European integration, this paper has shown that various other actors and factors have played a central role in preference formation, inter-state bargaining and ratification stage, notably: the change of leadership in France and the Netherlands; the pressures exercised by opposition parties and the media in the UK; the presence of euro-sceptical governments in Poland; the President of the Republic in Poland and in the Czech Republic; the Constitutional Court in Germany and in the Czech Republic. In line with institutionalist approaches, this paper has shown that some countries, Poland in primis, threatening to use their veto power managed to get important concessions. Moreover, some national negotiators managed to influence outcomes more than it would be expected by using the outcome of past referendum and the anticipated outcome of a future referendum. For instance, France wanted the elimination of free and undistorted competition from the objectives of the $\mathrm{EU}$ and the reassurance that the EU would protect its citizens; the Netherlands and the Czech Republic asked for various measures directed at strengthening the principle of subsidiarity; the United Kingdom raised the famous red lines to protect national sovereignty in sensitive areas such as social rights and judicial cooperation. In reality, a referendum was held only in Ireland, but paradoxically the Irish government did not use it as a bargaining chip.

More generally, this article has shown that the 'European issue' is no longer a matter of negotiations only between governments. Over the past decade, and for some this started already with the Treaty of Maastricht, European integration has met with increased resistance in various Member States. The mismatch between elites and public opinion and the politicisation of European integration has become a theme of a new strand of literature. In this sense, the 'permissive consensus' that characterised the early years of the European Union has increasingly turned into a 'constraining dissensus'. This does not mean that citizens have become more euro-sceptical everywhere, but more simply that "The European Union is no longer insulated from domestic politics; domestic politics is no longer insulated from Europe" (Hooghe and Marks 2009: 14). More domestic actors have gradually become more interested in the EU beyond governments and organised businesses. The negative referendum in Ireland, which followed those in France and in the Netherlands, is only the latest example of how controversial the issue of Europe has become. The entry into force of the Treaty of Lisbon, if the second referendum scheduled for autumn 2009 is successful, will finally put an end to a lengthy debate, which at times has diverted attention from more relevant issues, but will not mean that 'Europe' will stop being a highly salient issue among European citizens.

$* * *$

\section{Bibliography}

Beach, D. (2005). The dynamics of European integration: why and when EU institutions matter. Basingstoke: Palgrave Macmillan.

Beach, D. and Mazzucelli, C. (eds.) (2007). Leadership in the big bangs of European integration. Basingstoke: Palgrave Macmillan.

Beach, D. and Christiansen, T. (2007). 'Introduction: Political agency in the constitutional politics of the European Union', Journal of European Public Policy 14 (8), pp. 116366.

Bulmer, S. (1983). 'Domestic politics and European Community policy-making', Journal of Common Market Studies, 21 (4), pp. 349-63. 
Carbone, M. (2010). National Politics and European Integration: From the Constitution to the Lisbon Treaty. Cheltenham: Edward Elgar.

Castiglione, D., Schönlau, J., Longman, C., Lombardo, E., Pérez-Solórzano Borragán, N. and Aziz, M. (2007). Constitutional Politics in the European Union: The Convention Moment and its Aftermath. Basingstoke: Palgrave Macmillan.

Checkel, J. (2007). 'Constructivism and EU Politics', in K.E. Jørgensen, M.A. Pollack. and B. Rosamond (eds.), Handbook of European Union Politics. London: Sage, pp. 57-76.

Church, C. and Phinnemore, D. (2005). Understanding the European Constitution: An introduction to the EU Constitutional Treaty. London: Routledge.

Christiansen, T. (2008). 'The EU Treaty Reform Process since 2000: The Highs and Lows of Constitutionalising the European Union', Eipascope. Available at www.eipa.eu, last accessed 6 April 2009.

Christiansen, T., Falkner G., and Jørgensen, K.E. (2002). 'Theorising EU Treaty reform: beyond diplomacy and bargaining', Journal of European Public Policy 9 (1), pp. 1232.

Closa, C. (2004). 'The formation of domestic preferences on the reform of the Treaties in Spain', Comparative European Politics 2, pp. 320-338.

Closa, C. (2007). 'Why convene referendums? Explaining choices in EU constitutional politics', Journal of European Public Policy 14 (8), pp. 1311-32.

Dimitrakopoulos, D. and Kassim, H. (2004). 'Deciding the Future of the European Union: Preference Formation and the Treaty Reform, Comparative European Politics 2, pp. 241-60.

Dinan, D. (2008). 'Governance and Institutional Developments: Ending the Constitutional Impasse', Journal of Common Market Studies 46, Annual Review, pp. 71-90.

Dobson, L. and Føllesdal, A. (eds) (2004). Political Theory and the European Constitution. London: Routledge.

Eriksen, E., Fossum, J. and Meníndez, A. (eds) (2004). Developing a constitution for Europe. London: Routledge.

Falkner, G. (2002). 'Introduction: EU treaty reform as a three-level process', Journal of European Public Policy 9 (1), pp. 1-11.

Gourevitch, P. (2002). 'Domestic politics and international relations', in W. Carlsnaes, T. Risse, and B. Simmons (eds). Handbook of International Relations. London: Sage, pp. 309-28.

Hix, S. (2005). The Political System of the European Union. 2nd edition. London: Palgrave.

Hooghe, L. (2005). 'Several Roads Lead to International Norms, but Few Via International Socialisation: A Case Study of the European Commission', International Organization 59, pp. 861-898.

Hooghe, L. and Marks, G. (2009). 'A Postfunctionalist Theory of European Integration: From Permissive Consensus to Constraining Dissensus, British Journal of Political Science 39 (1), pp. 1-23.

Hug, S. and König, T. (2002). 'In View of Ratification: Governmental Preferences and Domestic Constraints in the Amsterdam Intergovernmental Conference', International Organisation 56, pp. 477-76.

Hug, S. and Schulz, T. (2007). 'Referendums in the EU's constitution building process', Review of International Organizations 2, pp. 177-218.

König, T. (2006). 'The Dynamics of the Two-Level Process of Constitution Building: Setting the Agenda by Agenda Setting, in S. Puntscher Riekmann and W. Wessels, (eds). The Making of a European Constitution: Dynamics and Limits of the Covention Experience. Wiesbaden.

König, T., Daimer, S., and Finke, D. (2008). 'The Treaty Reform of the EU: Constitutional Agenda-Setting, Intergovernmental Bargains and the Presidency's Crisis Management of Ratification Failure', Journal of Common Market Studies 46 (2), pp. 337-63.

König, T. and Finke, D. (2007). 'Reforming the equilibrium? Veto players and policy change in the European constitution-building process', Review of International Organization 2, pp. 53-76. 
König, T. and Hug, S. (2006). Policy-making Processes and the European Constitution: A Comparative study of Member States and Accession Countries. London and New York: Routledge.

König, T. and Slapin, J. (2006). 'From Unanimity to Consensus: An Analysis of the Negotiations at the EU's Constitutional Convention', World Politics 58, pp. 413-45.

Jabko, N. (2004). 'The Importance of Being Nice: an Institutionalist Analysis of French Preferences on the Future of Europe', Comparative European Politics 2 (3), pp. 282301.

Johansson, K. (2002). 'Another road to Maastricht: the Christian Democrat coalition and the quest for (the) European Union', Journal of Common Market Studies 40 (3), pp. 871-893.

Laursen, F. (ed) (2008). The Rise and Fall of the EU's Constitutional Treaty. Leiden and Boston: Martinus Nijhoff.

Magnette, P. and Kalypso N. (2004). 'The European Convention: Bargaining in the Shadow of Rhetoric', West European Politics 27 (3), pp. 381-404.

Marks, G., Hooghe, L. and Blank, K. (1996). 'European Integration since the 1980s. StateCentric Versus Multi-Level Governance', Journal of Common Market Studies 34 (3), pp. 343-78.

Milner, H. (1997). Interests, Institutions, and Information: Domestic Politics and International Relations. Princeton: Princeton University Press.

Moravcsik, A. (1993). 'Preferences and power in the European Community: A liberal intergovernmentalist approach', Journal of Common Market Studies 31 (4), pp. 473-523.

Moravcsik, A. (1997). 'Taking Preferences Seriously: A Liberal Theory of International Politics', International Organization 51 (4), pp. 513-53.

Moravcsik, A. (1998). The Choice for Europe: Social Purpose and State Power from Messina to Maastricht. Ithaca: Cornell University Press.

Moravcsik, A. and Nicolaïdis, K. (1999). 'Explaining the Treaty of Amsterdam: Interests, Influence, Institutions', Journal of Common Market Studies 37 (1), pp. 59-85.

Panke, D. (2006). 'More arguing than bargaining? The institutional designs of the European Convention and Intergovernmental Conferences compared', Journal of European Integration 28 (4), pp. 357-79.

Puetter, U. (2007). 'Intervening from outside: the role of EU finance ministers in constitutional politics', Journal of European Public Policy 14 (8), pp. 1293-1310.

Putnam, R. (1988). 'Diplomacy and domestic politics: The Logic of two-level games', International Organization 42 (3), pp. 427-60.

Reh, C. (2007). 'Pre-cooking the European Constitution? The role of government representatives in EU reform', Journal of European Public Policy 14 (8), pp. 11861207.

Richardson, J. (1982). Policy Styles in Western Europe. London: Allen and Unwin.

Risse, T. (2005). 'Neo-functionalism, European identities, and the puzzle of European integration', Journal of European Public Policy 12 (2), pp. 291-309.

Risse, T. and Kleine, M. (2007). 'Assessing the Legitimacy of the EU's Treaty Revision Methods', Journal of Common Market Studies 45 (1), pp. 69-80.

Rosamond, B. (2000). Theories of European Integration. New York: Palgrave.

Slapin, J. (2008). 'Bargaining Power at Europe's Intergovernmental Conferences: Testing Institutional and Intergovernmental Theories', International Organization 62, pp. 131-62.

Sandholtz, W. and Stone Sweet A. (eds) (1998). European Integration and Supranational Governance. Oxford: Oxford University Press.

Sverdrup, S. (2002). An institutional perspective on treaty reform: Contextualizing the Amsterdam and Nice treaties', Journal of European Public Policy 9 (1), pp. 120-140.

Taggart, P. (2006). 'Questions of Europe - The Domestic Politics of the 2005 French and Dutch Referendums and their Challenge for the Study of European Integration', Journal of Common Market Studies 44, Annual Review, pp. 7-25.

Wiener, A. and Diez, T. (2004). European integration theory., Oxford: Oxford University Press. 